\title{
KEMAMPUAN MENULIS PUISI BEBAS DENGAN MENERAPKAN METODE INKUIRI TERHADAP SISWA SMP NEGERI 3 GUNUNGSITOLI
}

\author{
Arozatulo Bawamenewi \\ Dosen Tetap IKIP Gunungsitoli (Yaperti Nias) \\ arozatulobawamenewi825@gmail.com
}

\begin{abstract}
Abstrak
Menulis merupakan kegiatan seseorang setiap hari dalam hal menuliskan simbol-simbol atau lambang-lambang untuk menuangkan ide atau berupa gagasan yang dimilikinya. Kegiatan menulis digunakan oleh orang terpelajar untuk mencatat atau merekam, meyakinkan, melaporkan atau memberitahukan dan mempengaruhi maksud serta tujuan seperti itu hanya dapat dicapai dengan baik oleh orang-orang yang dapat dicapai dengan baik oleh orang-orang yang dapat menyusun pikirannya dan mengutarakannya dengan jelas, kejelasan ini tergantung pada pikiran untuk pemakai kata-kata dan struktur kalimat metode inkuiri dapat digunakan sebagai metode pembelajaran yang dapat meningkatkan kemampuan siswa dalam menulis puisi. Metode inkuiri dapat memberikan motivasi dan dapat mengaktifkan siswa kelas VIII SMP Negeri 3 Gunungsitoli. Penerapan metode inquiri terdiri dari dua siklus, kemampuan siswa dalam menulis puisi dengan menggunakan strategi inquiri dapat meningkatkan kemampuan siswa dan mencpai KKM 75 yang telah ditetapkan.
\end{abstract}

Katakunci: metode inkuiri, menulis puisi bebas, siswa

\begin{abstract}
Writting is a daily activity for a person in writting symbolis of ideas. Writing is used by the educated to record, ensure, report annd persuade, in which depends on the skill that a writer owns related to the diction and the stucture of the sentence. The strategy of Inquiry was proven to be an effective way to improve the poetry writting ability of the students in SMP Negeri 3 Gunungsitoli class VIII, concerning to the motivation that prompts and the re-activation of the students. Thourgh the CAR research method in two cycles, the students ability in writting poetry by using the Inquiry strategy was increased, in which the MCC (KKM) of 75 is passed.
\end{abstract}

Keyword: metode inkuiri, menulis puisi bebas, siswa

\section{PENDAHULUAN}

\subsection{Latar Belakang Masalah}

Hasil observasi penulis di SMP Negeri 3 Gunungsitoli diperoleh informasi bahwa kemampuan siswa menulis puisi masih kurang, metode guru yang masih konvensional, kurangnya latihan siswa dalam menulis puisi, siswa merasa tidak memiliki bakat dalam menulis puisi, siswa merasa tidak mempunyai inspirasi dalam menulis puisi dan menganggap sulit.

Beberapa masalah di atas, menjadi penghambat pembelajaran menulis puisi di kelas khususnya di SMP Negeri 3 Gunungsitoli. Oleh karena itu, guru perlu mencari solusi agar siswa termotivasi dalam pembelajaran menulis puisi. Salah satu cara yang digunakan guru adalah dengan menggunakan Metode Inkuiri. Metode pembelajaran inkuiri adalah cara penyajian pelajaran dengan memberi kesempatan kepada peserta didik untuk menemukan informasi tanpa bantuan guru.

Dari uraian di atas, maka peneliti mengangkat judul rancangan penelitian tentang "Kemampuan Menulis Puisi Bebas dengan Menerapkan Metode 


\section{Inkuiri terhadap Siswa Smp Negeri 3 Gunungsitoli."}

\subsection{Rumusan Masalah}

1. Apakah ada peningkatan kemampuan siswa menulis puisi melalui Metode Inkuiri siswa kelas VIII SMP negeri 3 Gunungsitoli?

2. Apakah ada keaktifan dan sifat kooperatif siswa selama mengikuti pembelajaran melalui Metode Inkuiri?

3. Bagaimana pendekatan pembelajaran yang melibatkan komponen utama untuk meningkatkan kemampuan siswa menulis puisi.

\subsection{Tujuan Penelitian}

Tujuan penelitian ini adalah:

1. Untuk mendeskripsikan metode inkuiri dalam meningkatkan proses pembelajaran kemampuan menulis puisi bebas siswa kelas VIII SMP Negeri 3 Gunungsitoli Tahun Pembelajaran 2018/2019.

2. Mendeskripsikan kemampuan siswa dalam menulis puisi bebas.

3. Mendeskripsikan kemampuan siswa menulis puisi baru melalui metode pembelajaran.

\section{METODE}

Data yang digunakan dalam penelitian ini adalah bentuk instrumen berupa tes menulis puisi dan observasi. Teknik analisis data dalam penelitian ini ada dua, yakni analisis data kuantitatif dan analisis data kualitatif. Teknik analisis data kuantitatif (tes menulis puisi bebas) dapat dilakukan dengan menempuh langkah-langkah sebagai berikut:

a. Penskoran. Skor diberikan sesuai dengan kisi-kisi instrumen yang telah ditetapkan untuk memperoleh hasil tes kemampuan siswa dalam menulis puisi.

b. Penjumlahan skor. Setelah lembaran hasil menulis puisi siswa diberi skor sesuai dengan kisi-kisi instrumen, maka setiap skor dijumlahkan untuk mendapat skor akhir.

c. Penentuan Penilaian. Penentu batas minimal kelulusan dan penilaian nilai tertentu dapat dilakukan dengan perhitungan persentase.

d. Mencari rata-rata

Dalam menganalisis data yang ada peneliti mengklasifikasikan persentase semua persen. Peneliti menggunakan rumus mencari rata-rata yaitu:

$\mathrm{M}=\frac{\sum X}{N}$

Keterangan:

$\mathrm{M}=$ Mean (Nilai rata-rata)

$\sum X=$ Jumlah nilai total yang diperoleh dari hasil penjumlahan nilai setiap individu

$N=$ Banyaknya individu

Selanjutnya, tiap guru tentu saja dapat membuat atau memilih model yang dianggapnya paling sesuai baik yang menyangkut pengkategorian unsurunsurnya maupun besarnya bobot masing-masing unsur. Setelah dilakukan analisis data kuantitatif (hasil tes menulis puisi), dan analisis data kualitatif (hasil observasi) dengan menempuh tiga tahapan berikut yaitu:

a. Reduksi data, yaitu menyeleksi dan mengelompokkan data berdasarkan informasi dan diorganisasikan sesuai dengan pertanyaan peneliti.

b. Paparan data, yaitu bahwa data yang sudah terorganisasi dikelompokkan atau dideskripsikan sampai bermakna dalam bentuk tabel atau grafik ataupun dinarasikan.

c. Penyimpulan, yaitu bahwa berdasarkan paparan yang telah dibuat ditarik suatu kesimpulan dalam bentuk pernyataan atau formula singkat.

\section{HASIL DAN PEMBAHASAN}

Penelitian ini dilaksanakan di SMP Negeri 3 Gunungsitoli yang beralokasi di Kecamatan Gunungsitoli, 
Kota Gunungsitoli. Di sekolah ini terdapat satu kantor kepala sekolah, satu kantor guru, dan satu perpustakaan. Selain itu, sekolah ini memiliki kondisi lingkungan yang baik sehingga dapat mendukung kelancaran pelaksanaan penelitian.

Kemampuan Siswa Kelas VIII SMP Negeri 3 Gunungsitoli Dalam Menulis Puisi dengan Menggunakan Metode inkuiri

Peningkatkan kemampuan siswa menulis puisi dengan menggunakan metode inkuiri di kelas VIII SMP 3 Gunungsitoli Tahun Pembelajaran 2018/2019, peneliti melaksanakan penelitian dalam dua siklus yang terdiri dari dua kali pertemuan setiap siklus.

\section{Pelaksanaan Pembelajaran pada Siklus (I) Pertama}

Siklus pertama terdiri dari dua kali pertemuan. Agar lebih jelas pelaksanaan penelitian pada siklus pertama, dapat diuraikan berikut ini.

\section{1) Pertemuan Pertama}

Pertemuan pertama dilaksanakan dengan alokasi waktu $2 \times 40$ menit. Penelitian ini dilaksanakan di kelas VIII, dengan jumlah kesulurahan siswa adalah 18 orang. Pada pertemuan pertama, seluruh siswa tersebut telah mengikuti proses pelaksanaan kegiatan penelitian. Prosedur pelaksanaan penelitian pada pertemuan pertama adalah sebagai berikut:

\section{a) Perencanaan}

Sebelum melaksanakan tindakan di dalam kelas, terlebih dahulu peneliti mempersiapkan segala kebutuhan yang diperlukan saat menerapkan metode inkuiri, seperti: silabus, rencana pelaksanaan pembelajaran (RPP), materi pembelajaran, lembar observasi kegiatan peneliti dan siswa, dan lembar catatan guru pengamat.

\section{b) Tindakan}

Saat mengadakan tindakan di dalam kelas pada pertemuan pertama, peneliti masuk di dalam kelas dan menyapa serta menanyakan keadaan siswa. Agar ada feedback, peneliti melanjutkan tindakan untuk menanyakan apa saja materi yang sudah dipelajari sebelumnya kepada siswa.

c) Observasi

Pada fase observasi, guru pengamat (guru mata pelajaran bahasa Indonesia) membantu peneliti untuk mengamati segala apa yang terjadi selama metode inkuiri diaplikasikan di dalam kelas. Setelah mengamati seluruh aktivitas yang terjadi di dalam kelas, hasil observasi yang diperoleh dapat diuraikan yaitu siswa yang aktif dalam pembelajaran adalah 10 orang dari 18 orang siswa dengan persentase $55,56 \%$; dan siswa yang tidak aktif dalam pembelajaran adalah 8 orang dari 18 orang siswa dengan persentase $44,44 \%$. Selanjutnya, dalam menerapkan metode inkuiri pada pertemuan pertama, peneliti menemukan beberapa kelemahan yang diperbaiki.

d) Refleksi

Pada fase refleksi, peneliti mencatat, menganalisis, dan mengevaluasi hasil observasi serta melakukan perbaikan atas kelemahan yang ada pada pertemuan pertama. Adapun hal-hal yang perlu peneliti perbaiki pada pertemuan berikutnya, yaitu: mengontrol siswa agar tidak terjadi keributan di dalam kelas, memberikan contoh puisi bebas, menjelaskan penyesuaian isi puisi dengan topiknya.

\section{2) Pertemuan Kedua}

Tindakan dilaksanakan pada kelas VIII dengan jumlah siswa yang hadir pada saat itu adalah 18 orang siswa. Halhal yang dilaksanakan peneliti pada pertemuan kedua, pada hasil observasi masih terdapat kelemahan yang mestinya diperbaiki pada pertemuan berikutnya, yaitu sebagian siswa tidak mendengarkan 
penjelasan materi yang peneliti sampaikan, sebagian siswa tidak menulis pokok-pokok materi yang peneliti sampaikan, sebagian siswa tidak menghargai pendapat teman mereka. Pada tahapn refleksi, peneliti mencatat, menganalisis, dan mengevaluasi hasil observasi serta mencari solusi atas kelemahan yang terjadi pada pertemuan kedua siklus pertama. Kemudian peneliti manganalisis hasil evaluasi kemampuan siswa menulis puisi.

\section{Pembelajaran pada Siklus II (Kedua)}

Untuk mengetahui bagaimana pelaksanaan tindakan pada siklus kedua, dapat dilihat pada uraian berikut ini.

1) Pertemuan pertama. Pada pertemuan pertama, ada beberapa kegiatan yang peneliti lakukan yaitu:

\section{a) Perencanaan}

Peneliti menyediakan semua perangkat pembelajaran yang sudah diperbaiki, seperti: silabus, RPP, materi pembelajaran, lembar observasi peneliti maupun siswa, dan daftar hadir siswa.

b) Tindakan

Pada fase ini, kegiatan yang peneliti lakukan adalah masuk di dalam kelas dan menyapa siswa serta menanyakan keadaan mereka. Selanjutnya, tindakan yang dilakukan guru sebagai upaya perbaikan, peningkatan atau perubahan sebagai solusi. Maksudnya melakukan perbaikan terhadap kesalahan siswa dalam menulis puisi bebas

c) Observasi

Pada tahap observasi, guru pengamat mengobservasi semua aktivitas peneliti dan siswa serta apa saja yang terjadi di dalam kelas selama melaksanakan kegiatan pembelajaran. Adapun hasil observasi yang diperoleh, yaitu hasil observasi untuk siswa yang aktif dalam pembelajaran adalah 15 orang dari 18 orang siswa dengan persentase $83,34 \%$; dan siswa yang tidak aktif dalam pembelajaran adalah 3 orang dari 18 orang siswa dengan persentase $16,66 \%$.

Selanjutnya, pada catatan guru pengamat, ditemukan beberapa kelemahan yang perlu diperbaiki, yaitu: sebagian kecil siswa tidak bisa menulis puisi sesuai dengan yang diharapkan; sebagian siswa tidak mengerti apa yang dijelaskan peneliti. Di samping itu, peneliti menemukan beberapa kelebihan, yaitu siswa memiliki inisiatif untuk belajar, siswa mampu menggunakan bahasa yang ekspresif, siswa menghargai pendapat temannya, siswa mampu mengutarakan pendapat. Pada tahap ini, peneliti mencatat, menganalisis, dan mengavaluasi hasil penelitian. Selanjutnya, kelemahan yang perlu diperbaiki adalah menunjukkan kesalahan siswa dalam penulisan puisi, memberikan contoh serta memperkenalkan point-point penting dalam puisi.

2) Pertemuan kedua. Adapun uraian pelaksanaan penelitian pada siklus kedua dengan menerapkan metode pembelajaran inkuiri, yaitu:

\section{a) Perencanaan}

Peneliti menyediakan perangkat pembelajaran, seperti: silabus, RPP yang sudah diperbaiki, lembar observasi peneliti dan siswa.

b) Tindakan

Pada tahap tindakan, peneliti melaksanakan penelitian di dalam kelas. Peneliti menerapkan metode pembelajaran inkuiri terhadap kemampuan siswa menulis puisi bebas.

c) Observasi

Pada tahap observasi, guru pengamat membantu peneliti untuk mengamati semua aktivitas yang terjadi di dalam kelas, baik kegiatan peneliti maupun siswa. 
hasil observasi yang diperoleh pada pertemuan ini, dapat diuraikan yaitu hasil observasi untuk siswa. Siswa yang aktif dalam pembelajaran adalah 16 orang dari 18 orang siswa dengan persentase $89 \%$; dan siswa yang tidak aktif dalam pembelajaran adalah 2 orang dari 18 orang siswa dengan persentase $11 \%$;

\section{d) Refleksi}

Pada tahap refleksi, peneliti mencatat, menganalisis, mengevaluasi, dan menyimpulkan hasil penelitian. Kemudian, peneliti menganalisis hasil evaluasi kemampuan siswa menulis puisi. Hasil penelitian pada siklus kedua pertemuan kedua telah mencapai KKM yang sudah ditetapkan.

Masalah utama dalam penelitian ini adalah: "Bagaimana metode inkuiri meningkatkan kemampuan siswa menulis puisi kelas VIII SMP 3 Gunugsitoli Tahun Pembelajaran 2018/2019?" Dari masalah tersebut, dinyatakan bahwa penelitian ini bermanfaat untuk mendapatkan informasi tentang ada atau tidaknya peningkatan kemampuan siswa menulis puisi dengan menerapkan metode inkuiri.

\section{Analisis dan Penafsiran Temuan Penelitian}

Pada pertemuan pertama siklus pertama, siswa yang aktif dalam kegiatan belajar mengajar adalah 10 orang $(55,56 \%)$, sedangkan siswa yang tidak aktif adalah 8 orang $(44,44 \%)$. Terjadinya hal demikian disebabkan karena masih banyak kelemahan yang timbul saat melaksanakan kegiatan pembelajaran, seperti: siswa membuat keributan di dalam kelas, siswa masih belum mampu menggunakan kata-kata yang sesuai dalam puisi, siswa tidak mampu menulis isi puisi yang sesuai dengan topik atau judul puisi, dan masih banyak kegiatan yang belum dilaksanakan oleh peneliti.

Untuk mengatasi kelemahan tersebut, peneliti melakukan beberapa aktivitas, seperti: memotivasi siswa agar lebih serius lagi dalam mempelajari materi pembelajaran, menyarankan siswa untuk menulis ide-ide pokok yang peneliti sampaikan, membimbing siswa untuk belajar menghargai pendapat orang lain, dan peneliti mengusahakan untuk melaksanakan semua kegiatan yang telah disusun di RPP. Pada pertemuan kedua, siswa yang aktif dalam kegiatan pembelajaran adalah 16 orang (89\%), sedangkan siswa yang tidak aktif adalah 2 orang (11\%). Rata-rata nilai kemampuan siswa dalam menulis puisi pada siklus kedua adalah 80,27. Dari rata-rata nilai tersebut, dapat disimpulkan bahwa hasil penelitian sudah mencapai KKM yang telah ditetapkan. Dengan kata lain, kemampuan siswa menulis puisi telah meningkat setelah menerapkan metode inkuiri di kelas VIII SMP Negeri 3 Gunungsitoli Tahun Pembelajaran 2018/2019.

\section{Implikasi Temuan Penelitian}

Dari temuan penelitian yang sudah diperoleh, implikasi penelitian ini dapat diuraikan yaitu temuan penelitian ini dapat dijadikan sebagai bahan kepada siswa-siswi kelas VIII SMP Negeri 3 Gunungsitoli Tahun Pembelajaran 2018/2019 untuk meningkatkan kemampuan siswa dalam menulis puisi, hasil penelitian ini dapat digunakan oleh guru mata pelajaran Bahasa dan Sastra Indonesia sebagai metode pembelajaran yang tepat pada proses belajar mengajar khususnya pada materi menulis puisi, hasil penelitian ini dapat dijadikan sebagai acuan bagi peneliti berikutnyadalam melakukan penelitian lanjutan yang relevan dengan penelitian ini.

\section{Analisis dan Keterbatasan Temuan Penelitian}


Dalam penelitian ini keabsahan temuan penelitian pada hakikatnya tidak mutlak, hal ini disebabkan karena ada beberapa keterbatasan. Beberapa keterbatasan agar pandangan para pembaca sejalan dengan peneliti, antara lain: dalam penelitian ini, metode inkuiri hanya diterapkan di kelas VIII SMP Negeri 3 Gunungsitoli, dengan tujuan untuk meningkatkan kemampuan siswa menulis puisi, nilai rata-rata yang diperoleh dari tes kemampuan siswa dalam menulis puisi dengan menggunakan metode inkuiri akan berbeda hasilnya bila menggunakan konsep lain, dalam penelitian ini, perbadingan teori dengan temuan penelitian hanya sebatas pengetahuan dan pengalaman peneliti dalam melakukan penelitian ini, apa bila ada informasi yang baru atau yang lain maka kemungkinan teori dengan temuan dapat sejalan ataupun tidak.

\section{KESIMPULAN}

Penerapan metode inkuiri dapat meningkatkan kemampuan siswa menulis puisi di kelas VIII SMP Negeri 3 Gunungsitoli Tahun Pembelajaran 2018/2019. Metode inkuiri dapat digunakan sebagai metode pembelajaran yang dapat meningkatkan kemampuan siswa dalam menulis puisi. Metode inkuiri dapat memberikan motivasi dan dapat mengaktifkan siswa kelas VIII SMP Negeri 3 Gunungsitoli.

\section{DAFTAR PUSTAKA}

Arikunto, d. (2006). Penelitian Tindakan Kelas. Jakarta: Bumi Aksara.

Djamarah, S. B. (2010). Guru dan Anak Didik dalam Interaksi Edukatif. Jakarta: Rineka Cipta.

Herman, W. J. (2005). Apresiasi Puisi. Jakarta: PT Gramedia Pustaka Utama.

Kosasih. (2003). Ketatabahasaan dan Kesusastraan. Bandung: Yrama Widya.
N.K, R. (2008). Strategi Belajar Mengajar. Jakarta: Rineka Cipta.

Nurlathifah, P. (2009). Dunia Puisi. Bandung: Talenta Pustaka Indonesia.

Rahmat, P. D. (2009). Pengkajian Puisi. Yogyakarta: Gadjah Mada University.

Rasyid, M. (2009). Penilaian Hasil Belajar. Bandung: CV Wacana Prima. 